\title{
Level of Education and Perceptions of the Quality of Services to Prevent Radicalism: A Study in Poso District, Indonesia
}

\author{
Bambang Karsono \\ Faculty of Law Universitas Bhayangkara Jakarta Raya
}

\begin{abstract}
This study analyzes the differences in public perceptions of the quality of radicalism prevention services from the point of view of the level of education. Education has been used to radicalize and deradicalize youth. Governments in conflict-affected countries have an interest in funding measures against violent extremism as part of education programs. After the social conflict in the Poso district, the local government implemented some policies aimed at preventing the emergence of radicalism. The results of the study of 456 respondents from four elements of the population, namely the army, police, government employees, and the general public, showed that the level of education was the difference between people's perceptions of the quality of radicalism prevention services. Respondents with high school education were able to have a higher average response than those with a college education.
\end{abstract}

Keywords: education level, quality of service to prevent radicalism

\section{Introduction}

Preventing radicalization has become a significant issue in the debate on terrorism and sustainable development among developing countries. Sas et al. (2020) assert that radical individuals have a secondary or higher educational background. Ghosh (2018) finds that formal education can contribute to preventing youth radicalization. Radicalization prevention research is still important, but more important is the need for additional focus, namely on the socialization and education environment. That is, the level of education has a relationship with an understanding of radicalism. The higher one's education, the better one's understanding of the issue of radicalism, which in the end is expected to reduce the level of radicalism.

Radical has many meanings. A radical can be defined as the root of something or something that changes. Radical discusses or affects the main principle of something. Radicals lead to radicalism. To some extent, radicalism is dangerous, both from the government side or even the world. Some believe that terrorism occurs because of radicalism. Mubarok and Hamid (2018) noted that so many acts of terrorism were born from radicalism in Indonesia. One form of theory in the context of radicalism is what happened in Poso District, Central Celebes, Indonesia, which led to several social unrests in the community for 10 years, from 1998-2007.

The results of many studies show that there is a relationship between the level of education and radicalism. For example, Silber and Bhatt (2002) document that a large proportion of radicalized people have earned a degree in secondary or higher education. Krueger and Maleckova (2007) reported that most terrorists from the Middle East obtained a higher education degree. This evidence can be analogized that radicalism is related to the level of education. The higher a person's education, the higher the understanding of radicalism and the higher the expectation of services related to reducing radicalism.

The social unrest in Poso was one of the social conflicts that occurred in Indonesia at the beginning of the reform era. This riot lasted for quite a long time, approximately 10 years, from December 1998 to early 2007, and occurred in several stages, starting with the open conflict stage 3 times in 1998 to 2000, continuing with acts of terror and violence until early 2007. Overall, the Poso conflict has caused a large number of casualties, thousands of houses and public facilities were damaged or burned and tens of thousands of people became refugees. 
The handling of the Poso conflict began in August 2000, at which time the government introduced conflict resolution using a traditional approach. Then in 2001, hereinafter known as the Malino Declaration. In 2002, after monitoring, analysis, and evaluation, the government decided on a security restoration operation with a regional independence operation. The government's seriousness in the security sector is to upgrade the status of the Poso Police District to a special police station. Then the government promoted the community police program in the special Police District agenda.

The government's performance through the intelligence apparatus and the security forces relentlessly finally found its momentum after successfully identifying the terrorists who were later announced as DPO (List of People Searching). When the call to surrender was ignored, the security forces finally launched a law enforcement operation on January 22, 2007. The real result of this operation can be felt by the people of Poso, namely the establishment of a safe condition without terror disturbances that persists to this day.

The Poso conflict is a social riot that involves religious symbols in actions, discourses, and movements and even justifies violence to murder (Karnavian, 2008). Religious symbols in this case are Christianity (55 percent) and Islam (39 percent). This can be seen in the Laskar Jihad movement as a representation of the Islamic group and Laskar Christ as the representation of the Christian group. Each religious group uses religious symbols in actions, discourses, and movements. The composition of religion in Poso District is quite balanced between followers of Islam and Christianity (Christian and Catholic). Christians make up more than half of the population (55 percent), while the percentage of the population who are Muslims is around 40 percent. The rests are Catholics, Hindus or Buddhists, or other religions/beliefs.

This religion-based social conflict reached its peak when mass mobilization from outside Poso was coordinated by groups belonging to the Laskar Jihad organization (Hasan, 2006; Schulze, 2002). However, religion is not the only factor behind the Poso conflict, many factors are multi-rooted, interrelated with each other. One of them is the tribe.

The democratization process in Poso District since 1998 has changed the government bureaucracy based on power and political parties (the winner takes all) regardless of the cultural aspects of the Poso bureaucracy based on a balance between groups and groups. In the past, through the local Government person, the balance was always sought, for example, if the regent was from the Christian community, the representative would be sought from among the Muslims. And vice versa, thus harmonization occurs. However, with a democratic system, what is called "the winner takes all" occurs.

The complexity of the sources of the Poso conflict is accompanied by tensions between local political elites in the struggle for power and positions in the local government bureaucracy. Aditjondro (2004) asserts that one source of the Poso conflict and its protracted handling is the imbalance in public service policies in the community that is not balanced between Islam and Christianity.

The Poso conflict is a problem in structuring government policies during a society with a high level of plurality; ethnicity, religion, ethnicity, race, and gender that are not balanced with efforts for transparency and accountability. This is not in line with the tradition of bureaucratic management in Poso District where there is an unwritten agreement that public bureaucratic positions pay attention to the pattern of balancing elements of primordialism in Poso District. Therefore, the violation of this tradition has given rise to political tensions and the outbreak of riots and conflicts in the Poso District.

Several previous studies suggest that there are some roots to the outbreak of the Poso conflict. For example, local political elite tensions, ethnic and religious tensions, and socio-economic jealousy between indigenous people and migrants such as Bugis, Javanese, Gorontalo, and Kaili (Aditjondro, 2004; Arianto, 2005; Ecip, 2002; Karnavian, 2008). The tensions of the political elite in Poso District find their form in the struggle for power and government influence. The power struggle is getting out of control and even brings religion into the public sphere in discourse, action, and movement. Meanwhile, groups that lose in politics feel they are being treated unfairly because they do not get a strategic position in the government bureaucracy. Therefore, the Poso conflict is a space for political interests between elites to fight for power as a consequence of democracy that has not been fully understood and matured.

Geographically, Poso District has a special attraction that makes people come and live there. Several reasons could be put forward regarding this. For example, geographically the Poso area is very strategic in terms of its location and soil fertility. This condition causes the Poso area to always attract people's interest to inhabit it. Economic developments between the natives and immigrants, such as the Bugis, Javanese, Gorontalo, and Kaili, in turn, gave birth to socio-economic jealousy. The Poso conflict is exacerbated by the socioeconomic disparity. 
However, after the reformation in Indonesia, tensions began to emerge from the local political elite in the struggle for power and positions in the regional government bureaucracy. They compete for influence and power in politics and the bureaucracy by manipulating religious and ethnic identities. The climax was during the process of changing the regent of Poso, from late 1998 to 1999. Another thing that supported the conflict was the struggle for government bureaucratic positions, such as the election of the Regional Secretary which was full of religious and ethnic sentiments.

Another factor that also plays a role in the emergence of conflict escalation in Poso is the imbalance of public service policies in the community that is not balanced between Islam and Christianity. For example, groups that lose in political battles feel they are being treated unfairly because they do not get a strategic position in the government bureaucracy. The Poso conflict is a problem in structuring government policies amid a society with a high level of plurality; ethnicity, religion, ethnicity, race, and gender that are not balanced with efforts for transparency and accountability.

Another factor that is no less important as a trigger for conflict is the lack of strong ethnic and religious harmonization. Several chronologies of the riots explain that there are facts of religious symbols attached to victims, perpetrators, and the destruction of several places of worship. At the beginning of the reformation era, precisely in 1998, the peaceful situation in Poso District has torn apart. Starting from the incident of youth fighting, the conflict then developed into a conflict between adherents of Islam and adherents of Christianity. Open conflict in Poso District occurred 3 times, namely in December 1998, April 2000, and May to June 2000.

The emergence of hard-line religious groups (radical groups). Furthermore, the emergence of grudges from each of the conflicting radical groups, namely groups that have been involved in conflicts and have also been victims. The 1998 Reform Demands with an agenda for changes to good governance practices based on bureaucratic reform. Lack of community participation in conflict resolution efforts. The minimal involvement of community elements, for example, the dialogue that was held regarding the Poso issue only touched the elite (political elites, community leaders, and religious leaders). Included in this is the lack of involvement of non-state actors or institutions.

\section{Literature Review}

Theoretically, radicalism is not synonymous with violence, let alone anarchic actions, including juxtaposing it with certain religious groups. Radicalism is an understanding that wants a change or renewal in a drastic way to the very root. To achieve it involves many ways to the most extreme: both symbolic and physical violence. the word radical is used generally for those whose views are deeply rooted and perfect in their commitment (Stott, 2010). The word radical is found in the understanding of philosophy. It is stated that philosophy is defined as a radical and comprehensive way of thinking, a way of thinking that explores things as deeply as possible.

Dharmawan (2006) provides a framework of thought regarding the existence of communal conflicts in Indonesia, namely the radicalization of identity differences, the radicalization of communalism, and group interests. In other words, although there are differences regarding the sources of communal conflicts that occur in Indonesia, every conflict that occurs always raises issues of identity differences, communalism, and group interests. This further deepens the scale of communal social conflicts in the community's sphere of power.

One of the portraits of conflicts in the civil society sphere of power is the Poso conflict. The Poso conflict can be understood as a conflict in the sphere of civil society power that occurs because of a perspective in viewing social problems based on communalism values, although on the other hand there is a political element in it that also deepens the conflict. The Poso conflict became a space for debate and tensions over differences in identity, communalism, and the interests of the political elite, which triggered the outbreak of conflict and dragged on for a long time.

Sarwono (2012) defines radical as a positive feeling (affection) towards everything extreme, down to its roots. Radical is a strong attitude, called fanaticism. Radical attitudes will encourage motivation and behavior towards defending what they consider to be the most basic values of a belief, belief, ideology, or religion.

According to Kallen (1998), there are three general tendencies of radicalism characterization. The first is radicalism is a response to continuing conditions. The response seems in the form of assessment, refusal, or even confrontation. The rejected issues could be directly related to the situation, such as assumptions, ideas, 
institutions, or values . the second is radicalism does not stop attempts to reject, but there are efforts to replace the old order with a new order. This characteristic demonstrates that radicalism contains its worldview. Radicals are trying hard to make the order as a substitute for the existing order. The third is the radicals have a strong trust in the correctness of the program or ideology. Radicals fight for principles they contemplate are true with emotional attitudes leading to viciousness (Nelson and Olin, 1979).

Radicalism is a thought that requires changes and the cessation of a system in society to its roots. Radicalism needs a total change in the form or all facets of people's lives. Thus, the scope of the term radicalism depends on where we see and examine it. In this study, the author limits radicalism in the form of religion, which in this case means Islam.

Radicalism is not a problem providing it only competes in the thoughts of its adherents. However, when the radicalism of thought moves into radical movements, it begins to cause problems, particularly when their hopes to realize fundamentalism are blocked by other political forces because in that situation radicalism will be convoyed by violence. This phenomenon will usually lead to open conflict and violence between the two opposing groups (Turmudi and Sihbudi, 2005).

Participation that grows in society is influenced by many factors (Ross and Lappin, 1967). The factors influential to a person's tendency to partake are age, gender, education, profession and income, and length of stay. Education is considered capable of influencing a person's attitude in life towards his environment, an attitude that is needed to improve the welfare of the whole community (Ingleby, 2012).

\section{Research Methods}

The population of this research is the people of Poso District wherein in 2018 the number is around 230,000 people. Considering the size of the population, and the limited time and cost for collecting data through questionnaires, 500 questionnaires were sent randomly. The sample targets are the army, police, local government employees, and the community.

This research was conducted before the outbreak of the Covid-19 Pandemic, namely in 2018. Of the 500 questionnaires that were submitted directly to prospective respondents, 456 data were completely filled out and processed. The full details of the respondents are shown in Table 1. As shown in Table 1, respondents from the community element account for almost two-thirds of the total respondents, i.e., 62.50 percent. While the respondents from the police are the smallest representatives, 29 people or 6.36 percent.

Table 1. Distribution of Research Respondents

\begin{tabular}{|c|l|c|c|}
\hline No & Group & Number of people) & Percentage \\
\hline 1 & Soldier & 37 & 8.11 \\
\hline 2 & Police & 29 & 6.36 \\
\hline 3 & Local Government Employees & 105 & 23.03 \\
\hline 4 & Public & 285 & 62.50 \\
\hline & Total & 456 & 100.00 \\
\hline
\end{tabular}

\section{Research Variable}

There are two variables in this research, namely the level of education and the quality of services to prevent radicalism. The variable quality of service to prevent radicalism refers to the concept developed by Zeithaml et al. (1990) where there are 10 dimensions of service. Details of the variable indicators of the quality of radicalism prevention services are shown in Table 2.

Table 2. Indicators of the Quality of Service for the Prevention of Radicalism

\begin{tabular}{|c|c|c|}
\hline \multicolumn{3}{|c|}{ Dimension } \\
\hline \multirow{4}{*}{$\begin{array}{l}\text { Radicalism } \\
\text { Prevention } \\
\text { Service } \\
\text { Quality } \\
\text { Modification } \\
\text { of Zeithaml et } \\
\text { al. (1990) }\end{array}$} & 1. Tangible & $\begin{array}{l}\text { Physical facilities, personnel, and } \\
\text { communication }\end{array}$ \\
\hline & 2. Reliable & $\begin{array}{l}\text { The ability of the service unit in creating the } \\
\text { promised service appropriately. }\end{array}$ \\
\hline & 3. Responsiveness & $\begin{array}{l}\text { Service fees are determined in the service delivery } \\
\text { process. }\end{array}$ \\
\hline & 4. Competence & $\begin{array}{l}\text { Willingness to help the community take } \\
\text { accountability for the quality of services }\end{array}$ \\
\hline
\end{tabular}




\begin{tabular}{|l|l|l|}
\hline Variable & \multicolumn{1}{|c|}{ Dimension } & \multicolumn{1}{c|}{ Indicator } \\
\hline & \multicolumn{1}{|c}{ 5. Courtesy } & $\begin{array}{l}\text { Frovided. } \\
\text { responsive to the wishes of the community, and } \\
\text { making personal contacts or relationships. }\end{array}$ \\
\cline { 2 - 3 } & 6. Credibility & Honest attitude in every effort to win public trust. \\
\cline { 2 - 3 } 7. Security & $\begin{array}{l}\text { The services provided must be free from various } \\
\text { hazards and risks. }\end{array}$ \\
\cline { 2 - 3 } & 8. Access & There is the ease of contact and approach. \\
\cline { 2 - 3 } & $\begin{array}{l}\text { 9. Communication } \\
\text { The service providers'willingness to listen to the } \\
\text { voices, wishes, or aspirations of the community, } \\
\text { including the willingness to continually convey } \\
\text { new information to the community. }\end{array}$ \\
\cline { 2 - 3 } & $\begin{array}{l}\text { 10. Understanding } \\
\text { the customer }\end{array}$ & $\begin{array}{l}\text { Make every exertion to discover the needs of the } \\
\text { community. }\end{array}$ \\
\hline
\end{tabular}

\section{Results And Discussion}

\section{Overview of the Conflict in Poso}

The so-called Poso conflict and violence are a series of open riots that occurred in Poso, Central Celebs involving Muslim and Christian groups. This riot can be divided into three parts, namely 1). The first Poso riots occurred from 25 to 29 December 1998, 2). The second Poso riots occurred from 17 to 21 April 2000, and 3). The third Poso riots occurred from 16 May to 15 June 2000.

There are no exact figures on the number of victims of these riots, but based on some official findings (police and NGOs) these incidents have killed at least 577 people and injured thousands of people. Thousands of houses were destroyed and tens of thousands of residents were displaced.

After the third period of violence ended, further violence continued in a unilateral and sporadic form of violence in the form of bombings, shootings, killings, and ill-treatment until early 2007, when the security forces carried out Law Enforcement Operations on January 22, 2007. Since then, the graph of violence has declined drastically. to date.

When the reform movement reached its peak in mid-May 1998, which was marked by the fall of the New Order government, most of the people got involved in the euphoria. In an instant, the socio-political atmosphere changed brightly after 32 years of being in a state of restraint. People call the open era enthusiastically, sometimes exceeding the measure that in any free situation there must be a common rule that is binding and is intended to manage life together. In some areas as far as rural areas, the themes of reform and overthrow are in the news every day. The student movement has become a role model for the common people, even though they do not understand all of its meaning.

At the same time, the post-New Order government tends to be powerless in controlling the freedoms that are being enjoyed by society. The government was very careful if it did not want to be branded as the successor of the New Order. Moreover, the constellation of political change only takes place in some buildings, under the theme of gradual reform. Much different from the political situation in the events of 1965-1966 changes that took place more convincingly. In addition, the country's economy is still experiencing a slump due to the multidimensional crisis. There is not much the government can do.

The excitement of reform and the euphoria at the end of 1998 caused the people of Poso to find a way to channel everything that was hidden and the reform government was unable to prevent it. This momentum then came into contact with the issue of the Poso District Head Election at the end of 1998. However, the local bureaucracy has long been a status symbol and proof of the control of a group in a certain area.

However, the issue of the Poso District Head Election is not the only factor. The successive incidents of conflict that seem to take place at almost the same time in several regions also raise the suspicion that there are several actors at the national level who designed these events or were at least involved in controlling or providing hotspots at the right place and time. In Poso, long before the Domestic Election, leaflets with the tribe, religion, ethnic, and among groups nuances were circulated that heated up the situation, as if they were conditioning something.

This factor can also be read as a trigger factor for clashes in Poso which have similarities with cases elsewhere, namely inter-ethnic or inter-religious youth fights. The quality of radicalism prevention services 
includes five aspects. 1) Transparent: open, easy, and admissible to all parties who need it and provided it is adequate and easy to understand; 2) Accountability: can be accounted for by the provisions of the legislation; 3) Conditional: following the conditions and capabilities of the service provider and recipient by adhering to the principles of effectiveness and efficiency; 4) Participatory: encouraging community involvement in the enactment of public services by taking into account the aspirations, needs and expectations of the community; 5) Equality of rights: not discriminating against ethnicity, race, religion, gender group, and economic status; and 6) The balance of rights and obligations: providers and recipients of public services must satisfy the rights and obligations of each party.

The questionnaire on the variable quality of radicalism prevention services has 10 dimensions, namely tangible, reliable, responsiveness, competence, courtesy, credibility, security, access, communication, and understanding the customer. All dimensions collect information about respondents' perceptions in Poso District, in this case, the Poso District community towards the quality of radicalism prevention services.

Table 3 presents data on respondents' answers based on choices at each level. From the table, it can be said that the quality of radicalism prevention services needs to be improved in Poso District. It can be seen that 57 percent of the respondents agree and strongly agree on improving the quality of radicalism prevention services in Poso District. None of the respondents answered strongly disagreed on all indicators of the quality of radicalism prevention services.

Table 3. Percentage of Respondents' Answers

\begin{tabular}{|c|l|c|}
\hline No. & Respondent's Perception & Percentage (\%) \\
\hline 1 & Strongly Disagree & $0 \%$ \\
\hline 2 & Do not agree & $3 \%$ \\
\hline 3 & Disagree & $39 \%$ \\
\hline 4 & Agree & $45 \%$ \\
\hline 5 & Strongly agree & $12 \%$ \\
\hline \multicolumn{2}{|c|}{ Total } & $100 \%$ \\
\hline
\end{tabular}

The complete data on the results of research on each indicator of the quality of radicalism prevention services are described as follows. From the tangible aspect, the results show that $55 \%$ of respondents agree and strongly agree that there is an increase in physical facilities, personnel or human resources, and communication. On the Reliable aspect, the results showed $49 \%$ of respondents agreed and strongly agreed that there was an increase in the ability to serve on time. From the Responsiveness aspect, the results showed that $54 \%$ of respondents agreed and strongly agreed that there was an increase in the quality of services provided through the speed of responding to public complaints. In the competence element, 57\% of respondents agree and strongly agree that there is an increase in knowledge and skills of human resources through the ability and skill to handle services.

In the courtesy aspect, it was found that $59 \%$ of respondents agreed and strongly agreed that there was an increase in friendly, friendly, responsive attitude or behavior to the wishes of the community. On the element of credibility, it is known that $53 \%$ of respondents agree and strongly agree that there is an increase in honesty to attract public trust. Regarding the security aspect, the results of the study show that $55 \%$ of respondents agree and strongly agree that there is an increased sense of security. So free from danger and risk. When viewed from the aspect of access, it is known that $64 \%$ of respondents agree and strongly agree that there is an increase in the ease of access to information from local governments. In the communication element, it is known that $65 \%$ of respondents agree and strongly agree that the apparatus is willing to listen to the voices and wishes of the community. On the indicator of understanding the customer, the results of the study show that $57 \%$ of respondents agree and strongly agree that there is an increase in the community's need for good governance.

From 456 respondents, it is known that the number of male respondents is 317 (69.50 percent) and female respondents are 139 (30.50 percent). Distribution data based on the gender of the respondents show that the majority of respondents are male, almost 70 percent. 
The distribution of respondents based on education level is shown in Table 4. It can be seen that almost twothirds of the respondents (63.60 percent have a high school education, while the remaining 36.40 percent posess a college education).

Table 4 Distribution of Respondents' Education Levels

\begin{tabular}{|l|l|c|c|}
\hline No & Level of education & Amount & Percentage \\
\hline 1 & Senior High School & 290 & 63.60 \\
\hline 2 & Diploma & 15 & 3.29 \\
\hline 3 & Bachelor & 135 & 29.61 \\
\hline 4 & Postgraduate & 16 & 3.51 \\
\hline & Amount & 456 & 100.00 \\
\hline
\end{tabular}

\section{Test Results of Group Difference}

The study analyzed the differences in respondents' perceptions of the quality of radicalism prevention services for residents in the Poso district. The level of education is divided into two groups, namely respondents with high school education and tertiary education. The results of the mean (median) difference test are shown in Table 5.

Table 5 Test Results for Differences in Perceptions

\begin{tabular}{|c|c|c|}
\hline Description & \multicolumn{2}{|c|}{ Analysis Results } \\
\hline Amount of data & High School $=290$ & College $=166$ \\
\hline Mean value & 3.387 & 3.237 \\
\hline Median Value & 3.333 & 3.200 \\
\hline Independent $\mathrm{t}$-test for means & $\begin{array}{c}\text { Equal variance Assumed } \\
\mathrm{t}=3.943 \mathrm{p}=0.000\end{array}$ & $\begin{array}{c}\text { Equal variance not- } \\
\text { Assumed } \mathrm{t}=3.849 \mathrm{p}=0.000\end{array}$ \\
\hline Mann-Whitney test for median & & $\mathrm{Z}=3.875 ; \mathrm{p}=0.000$ \\
\hline Conclusion & $\begin{array}{l}\text { There is a difference in } \\
\text { perception }\end{array}$ & $\begin{array}{l}\text { There is a difference in } \\
\text { perception }\end{array}$ \\
\hline
\end{tabular}

As shown in Table 5, the perception of respondents with high school education is on average higher than respondents with a college education, which is 3.387 compared to 3.237 . The same thing can also be seen from the median value, where the median value of respondents with high school education is 3.333 compared to 3.200 .

The results of the test on whether there are differences in respondents' perceptions show that respondents with high school education have higher perceptions than respondents with a college education. The results of the test with the mean difference test (t-test for mean difference) and the median difference test (MannWhitney test for median) show that the response of respondents with high school education is statistically higher and significant compared to the response of respondents with a college education.

The findings in this study are interesting to note because empirically respondents with lower education have higher perceptions than respondents with higher education. This is somewhat different from the general assumption that the level of education is positively correlated with perceptions of service quality.

If we look further, this result may be determined by the scope of the questions in the questionnaires related to the quality of radicalism prevention services. Lower education levels, in this case, high school education, believe that the quality of services to prevent radicalism is better than those with tertiary education.

Respondents with higher education seem to demand better services so that their choice of quality services to prevent radicalism is lower. In other words, respondents with tertiary education give a lower rating of service quality which is intended to prevent radicalism which in the end is expected to reduce acts of terrorism. Several previous studies have confirmed that terrorism activities are more pronounced and stronger in those who receive higher education (Alcala et al., 2017). This fact strengthens the argument for why respondents with tertiary education expect a higher quality improvement in radicalism prevention services when compared to those with high school education.

The view is that respondents with a university education background expect a high quality of radicalism prevention services. If higher education can be associated with expectations of better security and welfare, then this prediction is identical to that proposed by Khan et al. (2021) in Pakistan that the higher the level of concern about acts of terror, the lower the respondent's confidence in welfare. 


\section{Conclusion}

This study examines the different perceptions of people who experience social conflict, namely the people of Poso District, Central Celebes province. After experiencing difficult times, it is necessary to examine the extent to which people perceive the quality of radicalism prevention services provided by the government. This study focuses on whether or not there are differences in people's perceptions as seen from the level of education. The results of the study involving 456 respondents showed that people with high school education had a better perception of the quality of radicalism prevention services (higher) than those with a college education. There is an impression that respondents with tertiary education expect higher services for the government's role in preventing radicalism.

Two things must be considered as well as limitations in this study. The first is related to the characteristics of the respondents. The number of respondents in the high school education group is almost twice that of the higher education group. This of course will affect the proportionality of respondents and can affect the results. Therefore, future research can use a more proportional number of each group. The second is related to the respondent's knowledge of the conflict that occurred. The period of conflict that occurred more than 10 years before the distribution of the questionnaires could be the cause that the respondents did not experience the conflict directly and they were already in a very conducive situation. Therefore, future research can focus on respondents with a relatively old age range who have experienced direct conflict.

\section{References}

1. Aditjondro, G.J. (2004). Membedah Kembar Siam Penguasa Politik \& Ekonomi Indonesia: Metodologi Investigasi Korupsi Sistemik Bagi Aktivis dan Wartawan. Jakarta: Lembaga Studi Pers dan Pembangunan. (Dissecting the Siamese Twins Ruling Indonesia's Politics \& Economy: Methodology for Investigation of Systemic Corruption for Activists and Journalists).

2. Alcalá, H.E., Sharif, M.Z. and Samari, G. (2017). Social determinants of health, violent radicalization, and terrorism: A public health perspective. Health Equity, 1(1), 87-95. https://doi.org/10.1089/heq.2016.0016.

3. Arianto, S. (2005). Rumput Kering di Balik Anyir Darah Konteks Etno Religius dari Tragedi Kemanusiaan Poso. Palu: Yayasan Tanah Merdeka. (Dried Grass in Balik Anyir Blood the EthnoReligious Context of the Humanitarian Tragedy of Poso).

4. Dharmawan, A.H. (2006). Konflik-konflik Kekuasaan dan Otoritas Kelembagaan Lokal dalam Reformasi Tata-Kelola Pemerintahan Desa: Investigasi Teoretik dan Empirik, Bogor: Pusat Studi Pembangunan Pertanian dan Pedesaan. (Conflicts of power and local institutional authority in village governance reform: Theoretical and empirical investigation)

5. Ecip, S.S. (2002). Rusuh Poso, Rujuk Malino, Jakarta: Cahaya Timur. (Riot in Poso, Refer to Malino).

6. Ghosh, R. (2018). The potential of the ERC program for combating violent extremism among youth. Religion Education, 45(3), 370-386. https://doi.org/10.1080/15507394.2018.1546509.

7. Hasan, N. (2006). Laskar Jihad: Islam, Militancy and the Quest for Identity in Post-New Order Indonesia, Ithaca, NY: Cornell Southeast Asia Program.

8. Ingleby, D. (2012). Ethnicity, migration and the social determinants of health agenda. Psychosocial Intervention. 21(3), 331-341. https://doi.org/10.5093/in2012a29.

9. Kallen, H.M. (1998). Culture and Democracy in the United States, New York: Transaction Publisher.

10. Karnavian, M.T. (2008). Indonesian Top Secret: Membongkar Konflik Poso, Jakarta: Gramedia. (Indonesian Top Secret: Unravelling the Poso Conflict).

11. Khan, A., Bibi, S., Lyu, J., Alam, M., Khan, M.M., \& Nurunnabi, M. (2021). The quest of tourism and overall well-being: The developing economy of Pakistan. PSU Research Review. 5(2), 120140. https://doi.org/10.1108/PRR-07-2019-0022.

12. Krueger, A.B., \& Maleckova, J. (2002). Education, Poverty, Political Violence and Terrorism: Is There a Causal Connection. National Bureau of Economic Research: Cambridge, MA, USA.

13. Mubarok, M. Z., \& Hamid, A.F.A. (2018). The Rise of Radicalism and Terrorism in Indonesia and Malaysia. Review of Islam in Southeast Asia, 1(1), 29-43. 
14. Nelson, K.L. \& Olin, S.C. (1979). Why War?: Ideology, Theory, and History, Oakland, CA: University of California Press.

15. Ross, M.G. \& Lappin, B.W. (1967). Community Organization: Theory, Principles and Practice. Second Edition. New York: Harper \& Row Publishers.

16. Sarwono, S.W. (2012). Terorisme di Indonesia: Dalam Tinjauan Psikologi. Tangerang: Pustaka Alvabet. (Terrorism in Indonesia: A Psychological Review).

17. Sas, M., Ponnet, K., Reniers, G., \& Hardyns, W. (2020). The role of education in the prevention of radicalization and violent extremism in developing countries, Sustainability, 12(6), 1-12. https://doi.org/10.3390/su12062320.

18. Schulze, K.E. (2002). Laskar Jihad and the conflict in Ambon. The Brown Journal of World Affairs, 9(1), 57-69.

19. Stott, J.R.W. (2010). The Radical Disciple: Some Neglected Aspects of Our Calling, London: IVP Book.

20. Silber, M.D., \& Bhatt, A. (2007). Radicalization in the West: The Homegrown Threat. New York, NY: Police Department New York.

21. Turmudi, E. \& Sihbudi, R. (2005). Islam dan Radikalisme di Indonesia, Jakarta: LIPI Press. (Islam and Radicalism in Indonesia).

22. Zeithaml, V.A., Parasuraman, A., \& Berry, L.L. (1990), Delivering Quality Service: Balancing Customer Perceptions and Expectations. New York: The Free Press. 